\title{
Dinamika Kebijakan Negara dalam Pengelolaan Wakaf di Indonesia
}

\author{
Makhrus \\ Universitas Muhammadiyah Purwokerto \\ Corresponding e-mail : makhrus.ahmadi@gmail.com
}

\begin{abstract}
This article examines state policies / regulations and the impact of communities and waqf management institutions in Indonesia. The results of this research article use descriptive qualitative approach with data collection techniques using observation and documentation. State policies or regulations in the management of waqf in Indonesia have been started since the Dutch colonial government. Waqf becomes an Islamic financial institution which is marked by the establishment of Rad Agama or Religious Court (priesterrad) based on Statute Book No. 152 of 1882. The Dutch recognition is based on the settlement of Islamic law proposed by the public to the Shariah Court (Local Religion Court), but in its application regions with other regions vary. Post independence there are several government regulations regarding waqf, one of them is Government Regulation Number 28 of 1977 concerning Property Land Ownership which only regulates land representation and its use is limited to socio-religious activities. However, after the enactment of Law No. 41 of 2004 concerning Waqf causes the management of waqf to be more varied and creative including the existence of money waqf. The impact of state policy on community / waqf management institutions in the management of waqf in Indonesia has caused the management of waqf to be carried out institutionally and productively. Money Waqf can be managed for investments that provide many benefits for welfare and benefit to the community, so that it becomes one of the productive indicators of waqf management. In addition, the strengthening of waqf management carried out by socio-religious organizations, the Indonesian Waqf Board, and the Sharia Money Receive Sharia Financial Institution is carried out by providing an understanding of profit orientation, regulation, supervision, and public orientation.
\end{abstract}

Keyword: Policy; Country, Management, Waqf

Abstrak. Artikel ini mempelajari kebijakan/regulasi negara dan dampaknya masyarakat dan
institusi pengelolaan wakaf di Indonesia. Artikel hasil penelitian ini menggunakan
pendekatan kualitatif deskriptif dengan teknik pengumpulan data menggunakan observasi
dan dokumentasi. Kebijakan atau regulasi negara dalam pengelolaan wakaf di Indonesia
telah dimulai sejak pemerintahan kolonial Belanda. Wakaf menjadi institusi keuangan Islam
yang ditandai dengan berdirinya Rad Agama atau Pengadilan Agama (priesterrad)
berdasarkan staatsblad Nomor 152 Tahun 1882. Pengakuan Belanda tersebut berdasarkan
penyelesaian hukum Islam yang diajukan masyarakat ke Mahkamah Syar'iyyah (Peradilan
Agama Lokal), namun dalam penerapannya antara satu daerah dengan daerah lainnya
berbeda-beda. Pasca kemerdekaan terdapat beberapa peraturan pemerinah mengenai
wakaf, salah satunya Peraturan pemerintah Nomor 28 Tahun 1977 tentang Perwakafan
Tanah Milik yang hanya mengatur mengenai perwakafan tanah saja dan penggunaannya
hanya terbatas untuk kegiatan sosial-keagamaan. Namun, pasca berlakunya UU No. 41 
Tahun 2004 tentang Wakaf menyebabkan pengelolaan wakaf menjadi lebih variatif dan kreatif termasuk adanya wakaf uang. Dampak kebijakan negara terhadap masyarakat/institusi pengelola wakaf dalam pengelolaan wakaf di Indonesia menyebabkan pengelolaan wakaf harus dilakukan secara kelembagaan dan bersifat produktif. Wakaf uang dapat dikelelola untuk investasi yang memberikan banyak manfaat kesejahteraan dan kemaslahatan terhadap masyarakat, sehingga menjadi salah salah satu indikator pengelolaan wakaf secara produktif. Selain itu, penguatan pengelolaan wakaf yang dilakukan oleh organisasi sosial-keagamaan, Badan Wakaf Indonesia (BWI), dan Lembaga Keuangan Syariah Penerima Wakaf Uang (LKS-PWU) dilakukan dengan memberikan pemahaman orientasi keuntungan, regulasi, supervisi, dan orientasi publik.

Keyword: Kebijakan; Negara, Pengelolaan; Wakaf.

\section{PENDAHULUAN}

Wakaf memiliki peranan penting dalam kehidupan umat Islam. Pada era awal Islam keberadaan wakaf mampu menjadi jalan kesejahteraan umat Islam dalam beragam bentuk. Misalnya, pembangunan tempat ibadah, pendidikan, kesehatan, pelayanan sosial serta kepentingan umum lainnya. Keberadaan wakaf pun terus memberikan dampak signifikan dalam sendi-sendi kehidupan umat Islam. Sebab keberadaan wakaf sebagai bagian yang tidak terpisahkan dari ajaran Islam, tidak hanya memiliki dimensi spiritual sebagai upaya meningkatkan ketaqwaan kepada Allah SWT, tetapi memiliki dimensi sosial yang mampu memberikan kesejahteraan ekonomi umat.

Berkaitan dengan pengelolaan wakaf dalam sejarah Islam, ternyata wakaf memiliki peranan penting dalam mensukseskan peran besar masyarakat Islam, misalnya, lahan yang ditanami di Daulah Utsmaniyah Turki $75 \%$ berasal dari wakaf, pertengahan abad 19 saat penjajagan Francis terhadap Aljazair separuh dari lahannya adalah tanah wakaf (c) abad ke-19 sepertiga lahan yang ada merupakan tanah wakaf, pada tahun 1949 sekitar seperdelapan dari lahan pertanian merupakan tanah wakaf, di Iran pada tahun 1930 sekitar 30\% lahan yang ditanami adalah tanah wakaf (Rahmawati, 2016: 36). Bahkan secara kelembagaan pendidikan Universitas Al Azhar Mesir dalam aktivitas operasionalnya menggunakan dana wakaf, salah satunya dengan mengelola gedung dan perusahaan di terusan Suez.

Pengelolaan wakaf pada era modern semakin berkembang, salah satunya dengan adanya wakaf tunai (uang) yang memungkinkan pengelolaan wakaf menjadi maksimal. Salah tokoh yang berpengaruh dalam menggagas adanya wakaf tunai adalah M. Abdul Manan berhasil mengembangkan wakaf tunai di Bangladesh dengan menyatakan banyak sasaran yang bisa dicapai dengan adanya wakaf tunai. Bahkan perbankan mampu menjadi fasilitator untuk menciptakan wakaf tunai dalam pengelolaan wakaf dengan mobilisasi tabungan masyarakat dengan menciptakan wakaf tunai untuk kegiatan sosial atau meningkatkan investasi sosial dalam mengembangkan social capital market (Faqih, 2005:293). Adanya konsep dan aplikasi wakaf tunai menjadi salah satu wujud inovasi konsep dan praktik wakaf yang selama ini masih mendapatkan perhatian khusus dalam kajian fikih klasik. Sementara di Indonesia mengenai pentingnya pengelolaan wakaf secara maksimal dalam mendorong kesejahteraan kaum dhuafa, telah lama dipraktikkan secara kolektif oleh berbagai organisasi masyarakat (ormas) maupun institusi pendidikan. Sekalipun, kini telah 
berdiri Badan Wakaf Indonesia (BWI) sebagai salah satu badan semi otonom pemerintah yang memiliki wewenang dan pengelolaan (nazhir) wakaf di Indonesia. Bahkan adanya konsep dan praktik wakaf tunai sebagai salah satu inovasi filantropi Islam pun mendapatkan legitimasi oleh otoritas keagamaan seperti Majelis Ulama Indonesia (MUI) maupun Kementerian Agama Indonesia, sehingga harapannya adanya dukungan dan pengelolaan yang maksimal menyebabkan penggalian potensi dan pengelolaan wakaf dan dana filantropi Islam lainnya menjadi lebih maksimal dan terarah, serta memberikan dampak sosial-keagamaan dalam menyelesaikan persoalan mendasar kaum dhuafa.

Berkaitan dengan pengelolaan wakaf di Indonesia, berdasarkan data dari Direktorat Pemberdayaan Wakaf Kementerian Agama hingga Maret 2016 bahwa tanah wakaf di Indonesia 4.359.443.170 m2 yang terdiri dari 435.768 lokasi dengan rincian 287.160 lokasi telah bersertifikat dan 148.608 lokasi belum bersertifikat. Jumlah objek wakaf tersebut senantiasa akan semakin berkembang seiring semakin besarnya partipasi masyarakat dalam melaksanakan wakaf secara kelembagaan. Sedangkan terkait dengan wakaf tunai hingga Oktober 2016 telah ada 16 Lembaga Keuangan Syariah Penerima Wakaf Uang (LKS-PWU) yang telah beroperasi dan menerima wakaf tunai/uang. Selain itu, dengan adanya wakaf tunai memberikan kemudahan kepada masyarakat untuk melakukan wakaf yang dapat disesuaikan dengan kemampuan wakif, hal ini dikarenakan keberadaan wakaf tunai tidak selalu mensyaratkan dengan nominal yang besar, sehingga memungkinkan masyarakat untuk bisa melakukan wakaf. Potensi wakaf di Indonesia dapat dioptimalkan dengan memanfaatkan bonus demografi dan potensi kelas menengah yang rata-rata masih berada dalam usia produktif. Berdasarkan data sensus penduduk Badan Pusat Statistik Republik Indonesia pada tahun 2010 bahwa jumlah umat Islam di Indonesia sebanyak 207.176.162 jiwa, maka bila dari jumlah diberikan kesempatan untuk berwakaf sebesar Rp. 1.000/hari atau Rp. 30.000/bulan, maka potensi wakaf tunai di Indonesia dapat mendapai 7,2 triliun setiap bulannya.

Potensi wakaf di atas dapat capai dengan memaksimalkan pengelolaan objek wakaf dan ada dukungan negara dalam pengelolaan wakaf. Pengelolaan wakaf di Indonesia berdasarkan data dari Badan Wakaf Indonesia sementara ini utilitas pengelolaan atau penggunaan tanah wakaf di Indonesia sementara ini terbagai atas beberapa sektor yakni, 73,74 \% masjid, 30,13 \% mushola, 10, 61 sekolah, 4,23\% makan, 2,98 \% pesantren dan 8,32 $\%$ sosial lainnya. Sementara adanya dukungan negara dalam pengelolan wakaf salah satunya dengan adanya UndangUndang Nomor 41 Tahun 2004 tentang Wakaf yang memberikan kepastian pengelolaan wakaf secara kelembagaan. Namun, adanya undang-undang wakaf tersebut tidak secara serta memberikan dampak sistemik dalam pengelolaan wakaf yang ditandai dengan makin besarnya objek wakaf, sebab pengelolaan wakaf telah banyak dipraktikkan oleh berbagai organisasi masyarakat dan institusi pendidikan.

Pengelolaan wakaf di Indonesia pada prinsipnya sama halnya dengan pengelolaan zakat yang lebih dahulu banyak dilakukan oleh organisasi masyarakat maupun institusi pendidikan. Hal tersebut dibuktikan dengan tumbuh dan berkembangnya ormas dan institusi pendidikan mampu menjadikan wakaf dan zakat dapat kelola untuk kepentingan sosial, pendidikan, kesehatan dan lainnya. 
Oleh sebab itu, pengalaman ormas dan institusi pendidikan tersebut menjadi sangat penting untuk jadikan pertimbangan dalam pengelolaan wakaf di Indonesia, tidak dari segi kelembagaan, tetapi juga terkait kultur masyarakat dan keberpihakan negara dalam pengelolaan wakaf dan filantropi Islam secara umum. Hal tersebut dikarenakan relasi antara masyarakat (rakyat) dan negara dalam banyak kejadian mengalami pasang surut yang terkadang menyebabkan rakyat harus berhadapan dengan negara. Sehingga, pada konteks pengelolaan kelembagaan modern bentuk konfrontatif tersebut harus senantiasa dihindari yakni dengan melakukan pola-pola kolaboratif dan integratif dalam berbagai aspek. Dinamika kebijakan negara selalu menemukan momentumnya sendiri dalam sudut pandang masyarakat, tidak terkecuali dalam konteks pengelolaan wakaf. Maka, guna memahami regulasi negara dan kontestasi masyarakat dalam pengelolaan wakaf diperlukan pemahaman dan pemaknaan yang menyeluruh agar bentuk kolaborasi dan integrasi antara kebijakan dan kontestasi pengelolaan wakaf tersebut dapat berjalan secara maksimal.

\section{METODE PENELITIAN}

Jenis penelitian ini merupakan penelitian kepustakaan (library research) yang mengandalkan data-data dari perpustakaan mengenai berbagai regulasi negara dalam pengelolaan wakaf di Indonesia. Selain itu, peneliti juga melengkapi penelitian ini dampak regulasi tersebut tehadap lembaga pengelola wakaf, sehingga bentuk penelitian ini bersifat deskriptif kualitatif. Maka, dokumentasi dari regulasi pemerintah yang meliputi undang-undang, peraturan pemerintah, peraturan menteri, informasi media, literatur, serta laporan dampak regulasi tersebut terhadap masyarakat atau pengelola wakaf di Indonesia juga bahan dalam penelitian ini. Sementara teknik pengumpulan data dilakukan dengan dokumentasi, observasi, dan kecukupan referensi. Kemudian, analisis data yang diperoleh, disajikan secara diskriptif dimulai dengan memaparkan kebijakan negara mengenai pengelolaan wakaf. Selain itu, kecukupan data-data perpustakaan yang dipelajari telah dikumpulkan sebelumnya serta data yang sudah terkumpul dianalisis secara kualitatif dengan metode deduktif dan induktif.

\section{HASIL DAN PEMBAHASAN}

\section{A. HASIL}

Wakaf merupakan salah satu dimensi paling strategis dalam ajaran agama Islam, sebab keberadaan wakaf tidak hanya menyangkut dimensi pribadi seorang muslim, melainkan juga mampu memberikan dampak positif terhadap kehidupan masyarakat secara umum. Keberadaan wakaf sama halnya zakat, memberikan peranan strategis dalam menyelesaikan persoalan umat manusia, seperti, kemiskinan, kebodohan, kesenjangan sosial dan lainnya. Oleh sebab itu, kesadaran melakukan wakaf secara kelembagaan yang mampu menggali potensi wakaf dan dana filantropi Islam lainnya. Kesadaran masyarakat dalam melaksanakan wakaf di Indonesia senantiasa menunjukkan perkembangan yang signifikan. Bukti antusiasme masyarakat tersebut dapat dilihat dengan tiga aspek, yakni: pertama, tranformasi keagamaan yang ditandai adanya birokratisasi dan modernisasi pada lembaga filantropi Islam. Kedua, dinamika pendistribusian dana filantropi Islam melalui program sosial termasuk diantaranya turut berperan aktif misi kemanusiaan, penanggulangan bencana dan memberi bantuan di lokasi konflik. Ketiga, adanya inovasi pada konsep- 
konsep dasar filantropi Islam yang melegitimasi penggalangan dana sosial dari masyarakat umum (Latief, dkk, 2015: 67-68). Selain itu, bentuk antusiasme tersebut lainnya terlihat dari adanya beberapa penelitian yang menunjukkan gerakan wakaf terus menunjukkan perkembangan pengelolaan, tidak hanya di Indonesia, tetapi juga secara global, sehingga pengelolaan wakaf menjadi lebih maksimal didasarkan pada basis data riset yang menjadi bentuk evaluasi dan akurasi potensi wakaf di Indonesia yang dapat digali secara optimal oleh pengelola wakaf.

Dinamika pengelolaan wakaf sebenarnya telah banyak dilakukan dilakukan peneliti wakaf. Salah satunya dilakukan Timur Kuran (2001) bahwa keberadaan wakaf Islam sebagai sebuah perangkat komitmen yang kredibel untuk memberi kepastian terhadap entitas ekonomi sebagai bagian dari layanan sosial, terlebih selama ini wakaf menjadi instrumen utama untuk pelayanan publik secara kolektif. Sementara Aunur Rohim Faqih (2005) memandang bahwa pengembangan institusi wakaf dan lembaga keuangan syariah memiliki spirit yang sama dalam meningkat ekonomi umat dalam memerangi kemiskinan dan ketergantungan. Hal tersebut dilakukan adanya manajemen pengelolaan yang profesional, amanah dan produktif yang selalu didasarkan pada syariat Islam dan peundang-undangan yang berlaku. Agus Triyanta dan Mukmin Zakie (2014) institusi pengelola wakaf memiliki peranan penting dalam sejarah dan peradaban Islam, sehingga berbagai institusi wakaf telah berfungsi sebagai tempat penyebaran ilmu dan budaya dengan memberikan kebebasan kepada para ulama dan budayawan untuk mengembangan keilmuan dan keahliannya. Sementara itu, pemanfaat tanah wakaf di Indonesia masih didominasi untuk keperluan tempat ibadah, prasarana sekolah, pemakaman, pesantren, sosial dan lainnya. Maka, diperlukan adanya perspektif baru mengenai wakaf, salah satunya dengan memanfaatkan obyek wakaf untuk kegiatan produktif, selain itu, juga dibutuhkan perbaikan kebijakan agraria yang memberikan dampak positif terhadap kesejahteraan serta turut berperan maksimal pengentasan kemiskinan dengan berbagai program yang lebih produktif.

Pengelolaan wakaf sebagaimana diteliti oleh Muhammad Aziz (2017) menunjukkan bahwa peranan Badan Wakaf Indonesia (BWI) melakukan pembinaan tehadap nazhir yang profesional, baik secara individu dan badan hukum yang diberi wewenang dan tanggung jawab sebagai nazhir wakaf uang. Upaya meningkatkan kualitas sumber daya manusia nazhir ini dilakukan secara tentatif dan tetap agar efek manfaatnya dapat dirasakan secara langsung oleh para nazhir. Sementara berkaitan wakaf tunai menurut Hilman Latief, Syarif As'ad dan Miftakhul Khasanah (2015) bahwa praktik pengelaan wakaf tunai yang dilakukan lembaga filantropi dan lembaga keuangan syariah, semakin menunjukaan untuk penggalangan dana terhadap kaum menengah muslim dengan praktik yang sangat dinamis dan inovatif. Sementara dalam konteks sosial ekonomi latar belakang pengelolaan wakaf tunai, sehingga dalam praktiknya menjadi sangat dinamis, tidak seragam dan sangat lentur, hal ini disebabkan adanya orientasi terhadap kemaslahatan ketimbang aspek hukumnya, baik hukum normatif dan positif. Penelitian evaluatif terhadap pengelolaan wakaf menurut Azharsyah Ibrahim (2014) bahwa pasca terjadinya 
bencana tsunami diaceh menyababkan terjadinya stagnasi perwakafan di Aceh, hal tersebut setidaknya disebabkan oleh empat hal yakni: terjadinya peningkatan harga tanah secara signifikan, adanya pergeseran nilai-nilai kemasyarakatan masyarakat menjadi cenderung materalistik, mulai memudarnya nilai-nilai sosial dan persaudaraan, serta banyaknya harta wakaf yang terbengkai dan tidak produktif.

Pengertian wakaf (al-waqf) secara bahasa berarti al-habs, dalam bahasa Indonesia berarti menahan. Sementara menurut Sayyid Sabiq (1987: 148) waqafayaqifu-waqfan yang berarti habasayahbisu-habsan. Kemudian, kata al-waqfu bila dijamakkan menjadi al-awqaf dan wuquf, sementara bentuk kata kerja (fi'il) adalah waqafa yang bermakna menahan atau mencegah (Aziz, 2017:189). Secara terminologi, wakaf adalah menyerahkan suatu hak milik yang tahan lama zatnya kepada seorang nazhir (penjaga wakaf) atau kepada suatu badan pengelola, dengan ketentuan bahwa hasil dan manfaatnya digunakan kepada hal-hal yang sesuai dengan ajaran syariat Islam (Ali, 1988: 80). Sedangkan secara regulatif menurut Undang-Undang Republik Indonesia Nomor 41 Tahun 2004 BAB I Pasal 1 Point 1, wakaf adalah perbuatan hukum untuk memisahkan dan/atau menyerahkan sebagian harta benda miliknya untuk dimanfaatkan selamanya atau untuk jangka waktu tertentu sesuai dengan kepentingannya guna keperluan ibadah dan/atau kesejahteraan umum menurut syariah.

Berdasarkan pengertian Undang Undang tentang wakaf tersebut di atas, maka jangka waktu wakaf tebagi atas dua bentuk, yakni: pertama, wakaf abadi yakni jenis harta wakaf yang diikrarkan oleh wakif kepada nadhir dalam jangka waktu yang tidak terbatas (selamanya), sehingga bentuk wakaf ini dapat dimanfaatkan dalam jangka panjang dengan tetap memanfaatkan kepentingan wakaf tersebut. Kedua, wakaf jangka waktu tertentu (sementara) yakni jenis harta wakaf yang diikrarkan wakif kepada nazhir untuk jangka waktu tertentu (tidak selamanya/abadi), baik dikarenakan bentuk barangnya maupun keinginan wakif itu sendiri. Berkaitan dengan pengelolaan objek wakaf, bila dilihat dari sudut pandang penggunaan harta yang diwakafkan, maka wakaf terbagi atas dua bentuk yakni: pertama, mubasyir/dzati yakni harta wakaf yang menghasilkan pelayanan masyarakat dan digunakan secara langsung, misalnya, rumah sakit, madrasah dan lainnya. Kedua, istitsmary yakni jenis harta wakaf yang ditunjukkan untuk penanaman modal dalam produksi barang-barang dan pelayanan yang diperbolehkan syara' dalam bentuk apapun, kemudian hasilnya dapat diwakafkan sesuai dengan keinginan wakif (Qohaf, tt:158-159). Sementara jenis harta wakaf sebagaimaa diatur dalam Peraturan Pemerintah Republik Indonesia Nomor 42 Tahun 2006 tentang pelaksanaan Undang-Undang Nomor 41 Tahun 2004 Bab III Pasal 15 menyebutkan bahwa jenis harta benda wakaf meliputi: benda tidak bergerak, benda bergerak selain uang dan, benda bergerak berupa uang. Namun, bila didasarkan pada tujuannya, wakaf terbagi atas tiga macam yakni: (a) wakaf sosial untuk kebaikan masyarakat (waqaf khairi) yakni apabila tujuan wakafnya digunakan untuk kepentingan umum, (b) wakaf keluarga (waqaf dzurri) yakni apalagi tujuan wakafnya digunakan guna memberi manfaat terhadap waqif, keluarga, keturunan, dan orang-orang tertentu tanpa melihat orang tersebut kaya-miskin, sehatsakit maupun tua-muda, (c) wakaf gabungan (waqaf musytarak) yakni apabila tujuan dan wakafnya digunakan 
untuk umum dan keluarga secara bersamaan (Aziz, 2017: 193).

Wakaf (waqf) berasal dari masdar dari kata kerja waqafa-yaqifu yang berarti "melindungi atau menahan", sinonim wakaf meliputi tahbis, tasbil atau tahrim, meskipun ketiga istilah yang terakhir ini kalah populer dibandingkan yang pertama (Widyawati, 2012: 32). Wakaf disyariatkan oleh Rasulullah shallallahu 'ailaihi wasallam (SAW) pada saat hijarah ke Madinah tepatnya pada tahun kedua Hijriyah. Namun, para fuqaha mengenai siapa yang pertama kali melakukan wakaf terdapat dua pendapat. Menurut sebagian ulama orang pertama kali melakukan wakaf adalah Rasulullah sendiri yakni pada saat Rasulullah mewakafkah tanahnya untuk dibangun masjid. Hal ini didasarkan pada hadits yang diriwayatkan oleh Umar bin Syabah dari 'Amr bin Sa'ad bin $\mathrm{Mu}^{\prime} \mathrm{ad}$, ia berkata: dan diriwayatkan dari Umar bin Syabah, dari Umar bin Sa'ad bin Muad berkata: "Kami bertanya tentang mula-mula wakaf dalam Islam? Orang Muhajirin mengatakan adalah wakaf Umar, sedangkan orang-orang Ansor mengatakan adalah wakaf Rasulullah SAW.". Kemudian, pada tahun ketiga Hijriyah, Rasulullah SAW juga pernah mewakafkan ketujuh kebun kurma di Madinah, diantaranya, kebun A'raf, Shafiyah, Dalal, Barqah dan kebun lainnya Pendapat kedua, orang pertama yang melaksanakan syariat wakaf menurut sebagian ulama adalah Umar bin Khatab. Hal ini didasarkan pada hadits yang diriwayatkan Ibnu Umar RA, ia berkata: "Bahwa sahabat Umar RA, memperoleh sebidang tanah di Khaibar, kemudian Umar RA, menghadap Rasulullah SAW untuk meminta petunjuk, Umar berkata : "Hai Rasulullah SAW., saya mendapat sebidang tanah di Khaibar, saya belum mendapat harta sebaik itu, maka apakah yang engkau perintahkan kepadaku?"
Rasulullah SAW. bersabda: "Bila engkau suka, kau tahan (pokoknya) tanah itu, dan engkau sedekahkan (hasilnya), tidak dijual, tidak dihibahkan dan tidak diwariskan. Ibnu Umar berkata: “Umar menyedekahkannya (hasil pengelolaan tanah) kepada orang-rang fakir, kaum kerabat, hamba sahaya, sabilillah, Ibnu sabil dan tamu. Dan tidak dilarang bagi yang mengelola (nazhir) wakaf makan dari hasilnya dengan cara yang baik (sepantasnya) atau memberi makan orang lain dengan tidak bermaksud menumpuk harta" Adanya syariat wakaf yang telah dilakukan oleh Umar bin Khatab kemudian disusul para sahabat Rasulullah SAW salah satunya Abu Thalhah yang mewakafkan kebun kesayangannya yakni kebun "Bairaha". Kemudian, Abu Bakar yang mewakafkan sebidang tanahnya di Mekkah yang diperuntukkan kepada anak keturunannya yang datang ke Mekkah, Utsman menyedekahkan hartanya di Khaibar, Ali bin Abi Thalib mewakafkan tanahnya yang subur, Mu'ads bin Jabal mewakafkan rumahnya yang kemudian populer dengan sebutan "Dar Al-Anshar", Anas bin Malik, Abdullah bin Umar, Zubair bin Awwam dan Aisyah Isri Rasulullah SAW.

Perkembangan praktik pengelolaan wakaf terus pun terus mengalami pengelolaan dan perkembangan secara signifikan. Khususnya, pada era kekhalifaan Umayyah dan Abbasyiyah. Pada era kedua dinasti besar Islam ini, wakaf tidak hanya diperuntukkan untuk membantu mensejahterahkan fakir miskin, melainkan juga dilakukan secara kolektif untuk membangun institusi pendidikan, perpustakaan, beasiswa hingga gaji pada guru sekolah dan penjaga perpustakaan. Dalam perkembangannya pengelolaan wakaf pun terus mengalami perkembangan secara signifikan secara kelembagaan pasca berakhirnya kedua 
dinasti besar Islam ini. Sementara pengelolaan wakaf di Indonesia secara praktik juga telah banyak dilakukan bahkan sebelum era kemerdekaan. Sekalipun belum didukung dengan berbagai perangkat regulasi yang memungkinkan pengelolaan wakaf dapat secara aplikatif menyentuh berbagai aspek wakaf. Regulasi sederhana sederhana ini pun tetap berjalan secara baik secara praktik kelembagaan, baik dilakukan secara kolektif oleh institusi pendidikan maupun organisasi sosialkeagamaan.

Pranata wakaf sebenarnya telah banyak dilakukan oleh kerajaan-kerajaan Islam di Nusantara, hal ini tersebut tergambar dari adanya hukum adat yang tidak tertulis yang mengambil sumbernya dari hukum Islam. Karenanya, pada saat pemerintahan Kolonial Belanda, wakaf menjadi institusi keuangan Islam yang ditandai dengan berdirinya Rad Agama atau Pengadilan Agama (priesterrad) berdasarkan staatsblad Nomor 152 Tahun 1882. Pengakuan belanda berdasarkan penyelesaian hukum Islam seperti wakaf dan lainnya diajukan masyarakat ke Mahkamah Syar'iyyah (Peradilan Agama Lokal), namun dalam penerapannya antara satu daerah dengan daerah lainnya berbeda-beda. Namun, pasca kemerdekaan permasalahan mengenai wakaf menjadi wewenang absolut dari Peradilan Agama selain masalah perkawinan, waris, hibah, sedekah, dan lainnya yang dipandang erat berkaitan dengan agama Islam. Pengelolaan wakaf di Indonesia terus mengalami perkembangan secara signifikan yang termanifestasi dalam beragam objek wakaf, khususnya dalam bidang pendidikan, sosial, kesehatan, dan lainnya. Sementara di sisi lain, kajian dan penelitian mengenai wakaf semakin menjadi bahan kajian yang terus menarik untuk dikupas oleh para akademisi dan praktisi, sehingga praktik wakaf mampu memberikan dampak positif terhadap kesejahteraan masyarakat dan di sisi yang lain juga memberikan empiris secara akademik. Apalagi, setelah Majelis Ulama Indonesia (MUI) pada tahun 2002 mengeluarkan fatwa yang memperbolehkan berwakaf dengan uang. Fatwa mengenai wakaf uang ini menjadi hasil ijtihad para ulama kontemporer, khususnya di Indoenesia yang mampu memberikan varian berwakaf bagi masyarakat Islam yang sebelumnya hanya memahami wakaf hanya sekadar tanah, masjid, dan benda wakaf lainnya yang non-uang. Adapun hasil Keputusan fatwa Komisi Fatwa MUI pada tanggal 28 Safar 1423 H/11 Mei 2002 M tersebut sebagai berikut ;

1. Wakaf uang (cash waqf, waqf annuqud) adalah wakaf yang dilakukan seseorang, kelompok orang, lembaga, atau badan hukum dalam bentuk uang tuna.

2. Termasuk ke dalam pengertian uang adalah surat-surat berharga.

3. Wakaf uang hukumnya jawaz (boleh)

4. Wakaf uang hanya boleh disalurkan dan digunakan untuk hal-hal yang diperbolehkan secara syar'iy (mushrib mubah)

5. Nilai pokok wakaf uang harus dijamin kelestariannya, tidak boleh dijual, dihibahkan, dan atau diwariskan.

Adanya fatwa MUI mengenai kebolehan berwakaf uang dan mendapatkan respon positif masyarakat di berbagai belahan dunia dan terbukti mampu membangun kesejahteraan masyarakat. Guna memberikan dampak sistemik mengenai pengelolaan wakaf secara regulatif juga mendapatkan respon positif yakni dengan adanya UndangUndang Nomor 42 Tahun 2004 tentang Wakaf dan peraturan-peraturan yang 
dikeluarkan oleh Badan Wakaf Indonesia (BWI). Adanya regulasi ini semakin memberikan peran besar terhadap pengelolaan wakaf di Indonesia sebelumnya tidak memiliki payung hukum formal (regulatif) yang mengikat dan hanya berpedoman terhadap kitabkitab fikih klasik. Namun, secara umum praktik wakaf di Indonesia menurut Ulya Kencana (2017: 16-18) terbagi atas tiga periodesasi sebagai berikut :

1. Wakaf dalam dataran praktik, pada periode ini setelah Islam masuk ke Nusantara dan secara politik menjadi hukum negara pada masa kerajaan Islam, secara praktik wakaf menjadi tradisi yang dilakukan oleh masyarakat Islam.

2. Wakaf dalam tataran masyarakat adat di Indonesia, pada periode ini hukum adat yang memandang bahwa lembaga wakaf yang berasal dari hukum Islam diterima (diresepsi) menjadi hukum adat di Indonesia.

3. Wakaf dalam dataran sebagai hukum negara, pada periode ini terbagi atas dua bagian yakni:

a. Masa penjajahan pemerintah Kolonial Belanda, pada masa periode ini wakaf menjadi momentum perkembangan organisasi sosial keagamaan yang mengelola wakaf untuk kegiatan keagaman saja, misalnya, wakaf untuk pembangunan sekolah, madrasah, pondok pesantren, dan masjid yang didirikan di atas tanah wakaf.

b. Masa pemerintahan Republik Indonesia, terbagi atas tahapan yakni:

1) Pasca kemerdekaan terdapat beberapa peraturan pemerinah mengenai wakaf. Salah satunya Peraturan pemerintah Nomor 28 Tahun 1977 tentang Perwakafan Tanah Milik yang hanya mengatur mengenai perwakafan tanah saja dan penggunaanya hanya terbatas untuk kegiatan sosial-keagamaan.

2) Sebelum tahun 2001 perkembangan wakaf mengalami kemandegan, hal ini adanya kurangnya regulasi yang mengatur mengenai wakaf. Namun, pada tahun 2001 para praktisi ekonomi Islam mengusung paradigma baru mengenai wakaf yakni konsep wakaf uang guna meningkatkan kesejahteraan masyarakat.

3) Tahun 2002 Majelis Ulama Indonesia mengeluarkan fatwa tentang diperbolehkannya wakaf uang sebagai respon dari kian menguat dan pentingnya wakaf uang.

4) Tahun 2004 secara reguatif wakaf memiliki Undang-Undang tersendiri yakni Undang Undang Nomor 41 Tahun 2004 tentang wakaf, yang memungkinkan masyarakat (nazhir) dapat mewakafkan harta benda tidak bergerak dan harta benda bergerak berwujud atau tidak berwujud uang yang dapat dikelola sebagai wakaf produktif.

Praktik wakaf yang telah banyak dilakukan oleh masyarakat Islam Indonesia termanifestasi terhadap pembangunan masjid, tanah, dan institusi pendidikan Islam yang dikembangkan secara berkelanjutan, termasuk aset benda wakaf bergerak dalam bentuk uang yang dikelola keabadian asetnya sehingga dapat memberkan kemaslahatan terhadap kehidupan masyarakat (Kencana, 2017:13). Adanya Nomor 41 Tahun 2004 tentang wakaf menjadi payung hukum pengelolaan wakaf di Indonesia yang menyebabkan pengelolaan menjadi lebih variatif. Sementara di sisi lain semakin 
membesarnya kesadaran masyarakat mengenai pentingnya pendidikan, kesejahtera masyarakat, dan pengelolaan wakaf secara kelembagaan turut menjadikan gerakan wakaf menjadi lebih masif. Adapun secara regulatif regulasi pengelolaan wakaf di Indonesia sebagai berikut:

1. Undang-undang yang berkaitan dengan wakaf :

a. Undang Undang Nomor 41 Tahun 2004 tentang Wakaf

b. Undang-Undang Nomor 50 Tahun 2009 tentang Perubahan Ketiga atas Undang Undang Nomor 7 Tahun 1989 tentang Peradilan Agama

2. Penjelasan Undang-Undang Nomor 41 Tahun 2004 tentang Wakaf

3. Peraturan Pemerintah tentang Wakaf :

a. Peraturan Pemerintah Nomor 28 Tahun 1977 tentang Perwakafan Tanah Milik

b. Peraturan Pemerintah Nomor 42 Tahun 2006 tentang pelaksanaan Undang-Undang Nomor 40 Tahun 2004.

4. Penjelasan Atas Peraturan Pemerintah Nomor 42 Tahun 2006 tentang pelaksanaan Undang-Undang Nomor 40 Tahun 2004

5. Keputusan Presiden Nomor 75/M Tahun 2007 ditetapkan di Jakarta tanggal 13 Juli 2007 tentang Keanggotaan Badan Wakaf Indonesia yang diangkat oleh Presiden Republik Indonesia

6. Instruksi Presiden Nomor 1 Tahun 1991 tentang Kompilasi Hukum Islam Buku III Hukum Perwakafan

7. Peraturan Menteri Agama Nomor 4 Tahun 2009 tentang Administrasi Pendaftaran Wakaf Uang
8. Peraturan Menteri Agama Nomor 73 Tahun 2013 tentang Tata Cara Perwakafan Benda Tidak Bergerak dan Benda Bergerak Selain Uang.

9. Kepetusan Direktur Jenderal Bimbingan Masyarakat Islam Nomor DJ.II/420 Tahun 2009 tentang Model, Bentuk, dan Spesifikasi Formulir Wakaf Uang

10.Surat Keputusan Menteri Agama Republik Indonesia tentang Daftar Lembaga Keuangan Syariah Penerima Wakaf Uang

11.Fatwa Majelis Ulama Indonesia tanggal 11 Mei 2002 tentang Wakaf Uang

12.Himpunan Peraturan Badan Wakaf Indonesia tentang wakaf di Indonesia :

a. Peraturan Badan Wakaf Indonesia Nomor 1 Tahun 2007 tentang Organisasi dan Tata Kerja Badan Wakaf Indonesia

b. Peraturan Badan Wakaf Indonesia Nomor 1 Tahun 2008 tentang Prosedur Penyusunan Rekomendasi terhadap Permohonan Penukaran/Perubahan Status Harga Benda Wakaf.

c. Peraturan Badan Wakaf Indonesia Nomor 3 Tahun 2008 tentang Tata Cara Pendaftaran dan Penggantian Nazhir Harta Benda Wakaf Tidak Bergerak Berupa Tanah.

d. Peraturan Badan Wakaf Indonesia Nomor 1 Tahun 2009 tentang Pedoman Pengelolaan dan Pengembangan Harta Benda Wakaf Berupa Uang.

e. Peraturan Badan Wakaf Indonesia Nomor 2 Tahun 2009 tentang Pedoman Penerimaan Wakaf Uang Bagi Nazhir Badan Wakaf Indonesia.

f. Peraturan Badan Wakaf Indonesia Nomor 1 Tahun 2010 tentang Tata 
Cara

Pengangkatan

dan

Pemberhentian Anggota Badan Wakaf Indonesia.

g. Peraturan Badan Wakaf Indonesia Nomor 2 Tahun 2010 tentang Tata Cara Pendaftaran Nazhir Wakaf Uang

h. Peraturan Badan Wakaf Indonesia Nomor 4 Tahun 2010 tentang Pedoman Pengelolaan dan Pengembangan Harta Wakaf.

i. Peraturan Badan Wakaf Indonesia Nomor 2 Tahun 2012 tentang Perwakilan Badan Wakaf Indonesia.

Beragam perangkat regulasi negara dalam pengelolaan wakaf $\mathrm{di}$ atas berimplikasi terhadap pengelolaan wakaf secara terlembaga dan profesional. Sebelum adanya Undang Undang Nomor 41 Tahun 2004 tentang Wakaf secara praktik pengelolaan wakaf hanya dilakukan oleh organisasi sosialkeagamaan. Pasca berlakunya UndangUndang Nomor 41 Tahun 2004 tentang Wakaf berimplikasi terhadap adanya paradigma baru mengenai jenis benda yang dapat diwakafkan oleh masyarakat Indonesia, salah satunya diperbolehkannya wakaf uang. Sementara penguatan kelembagaan terhadap institusi pengelola wakaf dalam pengelolaan wakaf di Indonesia, selain oleh organisasi sosialkeagamaan yang telah lama melakukan pengelolaan wakaf yakni adanya terhadap Badan Wakaf Indonesia (BWI) dan Lembaga Keuangan Syariah Penerima Wakaf Uang (LKS-PWU). Berkaitan dengan tugas dan wewenang BWI sebagaimana telah diatur dalam Peraturan Badan Wakaf Indonesia Nomor 1 Tahun 2007 tentang Organisasi dan Tata Kerja Badan Wakaf Indonesia Pasal 8 menyebutkan bahwa :
1. Melakukan pembinaan terhadap nazhir dalam mengelola dan mengembangkan harta benda wakaf;

2. Membuat pedoman pengelolaan dan pengembangan harta benda wakaf;

3. Melakukan pengelolaan dan pengembangan harta benda wakaf berskala nasional dan internasional serta harta benda wakaf terlantar;

4. Memberikan pertimbangan, persetujuan dan/atau ijin atas perubahan peruntukan dan status harta benda wakaf;

5. Memberikan pertimbangan, persetujuan atas penukaran harta benda wakaf;

6. Memberikan saran dan pertimbangan kepada Pemerintah dalam penyusunan kebijakan di bidang perwakafan;

7. Menerima, melakukan penilaian, menerbitkan tanda bukti pendaftaran Nazhir, dan mengangkat kembali nazhir yang telah habis masa baktinya;

8. Memberhentikan dan mengganti Nazhir bila diperlukan;

9. Memberikan saran dan pertimbangan kepada Menteri Agama dalam menunjuk Lembaga Keuangan Syariah Penerima Wakaf Uang (LKS-PWU);

10.Menerima pendaftaran Akta Ikrar Wakaf (AIW) benda bergerak selain uang dari Pejabat Pembuat Akta Ikrar Wakaf (PPAIW).

Keberadan Lembaga Keuangan Syariah Penerima Wakaf Uang (LKS-PWU) tidak bisa dilepaskan dari peran dan semakin berkembangan lembaga keuangan syariah di Indonesia. Oleh sebab itu, keberadaan LKS-PWU berfungsi sebagai lembaga keuangan syariah yang menerima wakaf uang, menyediakan blangko wakaf uang, sampai dengan mendaftarkan wakaf uang 
kepada Menteri Agama atas nama nazhir. Berdasarkan data BWI pada bulan oktober tahun 2016 telah terdapat 16 LKS-PWU sebagai berikut :

Tabel 1. Daftar LKS-PWU

\begin{tabular}{|c|c|c|}
\hline No. & Nama LKS-PWU & $\begin{array}{c}\text { Tahun } \\
\text { Terdaftar }\end{array}$ \\
\hline 1. & Bank BNI Syariah & 2008 \\
\hline 2. & Bank Muamalat & 2008 \\
\hline 3. & Bank DKI Jakarta & 2008 \\
\hline 4. & $\begin{array}{l}\text { Bank Syariah } \\
\text { Mandiri }\end{array}$ & 2008 \\
\hline 5. & Bank Mega Syariah & 2008 \\
\hline 6. & Bank BTN Syariah & 2010 \\
\hline 7. & $\begin{array}{l}\text { Bank Syariah } \\
\text { Bukopin }\end{array}$ & 2010 \\
\hline 8. & $\begin{array}{l}\text { Bank } \\
\text { Pembangunan }\end{array}$ & 2010 \\
\hline & $\begin{array}{l}\text { Daerah Syariah } \\
\text { Yogyakarta }\end{array}$ & \\
\hline 9. & BPD Jateng & 2010 \\
\hline 10. & BPD Kalbar & 2010 \\
\hline 11. & BPD Riau & 2010 \\
\hline 12. & BPD Jatim & 2010 \\
\hline 13. & BPD Sumut & 2012 \\
\hline 14. & CIMB Syariah & 2013 \\
\hline 15. & Panen Syariah & 2014 \\
\hline 16. & BPD Sumsel\&Babel & 2016 \\
\hline
\end{tabular}

\section{B. PEMBAHASAN}

Secara praktik pengelolaan harta benda wakaf di Indonesia telah banyak dipraktikan semenjak jaman penjajahan Kolonial Belanda. Biasanya, hal tersebut, masih dalam bentuk tanah, sekolah, masjid, kuburan dan lainya. Sekalipun, dalam beberapa kejadian terdapat harta benda wakaf sering tidak terurus, pemanfaatannya tidak sesuai dengan tujuan, bahkan kadang-kadang wakaf dialihkan kepada pihak lain oleh pengurus wakaf (nazhir), tapi tidak menutup kemungkinan tanah wakaf itu diminta kembali oleh orang yang mewakafkan tanah (waqif), atau dikuasai oleh pihak lain tanpa melalui prosedur hukum atau melawan hukum untuk kepentingan pribadi atau golongan, peristiwa-peristiwa penyelewengan hukum atas benda wakaf itu tidak lepas dari lemahnya perangkat hukum yang ada, termasuk didalamnya tidak bersertifikat. Penarikan kembali dalam arti apabila terjadi penyimpangan yang dilakukan oleh nazhir misalnya, dapat dilakukan apabila waqif telah menentukan syarat terhadap pemanfaatan benda wakaf itu. Jika pemanfaatan benda wakaf telah menyimpang dari tujuan dan syarat yang ditentukan, waqif dapat menarik kembali untuk kemudian diwakafkan kembali guna tercapainya tujuan utama wakaf, penarikan kembali tadi tidak dimaksudkan untuk dimilikinya kembali melainkan menjadi milik Allah. Maka, secara untuk menyelesaikan sengketa antar umat Islam juga digunakan hukum acara perdata yang berlaku di Indonesia. Demikian pula dalam sengketa wakaf, maka penyelesaian pun akan menggunakan hukum acara perdata yang berlaku di Indonesia. Untuk menghindari hal-hal yang dilakukan orang untuk menyelesaikan permasalahan dengan main hakim sendiri maka hukum menyediakan lembaga untuk menyelesaikan permasalahan tersebut yaitu di Pengadilan. Penyelesaian perkara perdata dilakukan dengan menggunakan hukum acara perdata.

Adanya permasalahan wakaf atau konflik mengenai harta benda wakaf (objek wakaf) dikarenakan masih kurangnya manajemen pengelolaan mengenai objek wakaf. Biasanya, hal demikian terjadi pada objek wakaf yang tidak tercatat dan lemahnya dokumen resmi. Namun, kini pengelolaan manajeman wakaf juga mengalami kemajuan yakni dengan adanya pengelolaan secara profesional dan tidak lagi menggunakan pola konvensional yang hanya mengandalkan azas kepercayaan dan ala kadarnya. Dengan manajemen yang profesional, pengelolaan wakaf akan 
lebih terasa manfaatnya untuk masyarakat luas (Wajdy\&Mursyid, 2007: 174). Tentu saja, semangat produktifitas kolektif baik dari waqif dan nadzir senantiasa harus dijaga sebagai tanggung jawab bersama untuk membangun kesejahteraan bersama masyarakat. Pola manejemen profesional pengelolaan wakaf barangkali juga dipengaruhi semangat wakaf tunai yang penah pelopori M. Abdul Mannan, yang memberikan kesempatan bagi banyak pihak untuk terlibat dalam pembangunan kesejahteraan, peningkatan produktifitas dan yang berperan dalam menyelesaikan problematika kemiskinan. meski pada hakikatnya wakaf juga berkaitan dengan kesejahteraan dan kemandirian umat Islam.

Dinamika praktik wakaf di Indonesia yang awalnya banyak dipraktikkan oleh organisasi sosial keagamaan menyebabkan objek wakaf termanifestasi dalam wujud masjid, sekolah, pesantren, dan berbagai praktik sosial keagamaan lainnya. Menurut Alya Kencana secara umum praktik wakaf di Indonesia dari diketahui dari beberapa aspek (2017: 16) yaitu: pertama, sejarah hukum wakaf yang mirip wakaf pada masa pra-Islam, wakaf pada masa Rasulullah dan sesudahnya, di Barat, dan hukum ada di Indonesia. Kedua, berdasarkan teori masuknya Islam di Indonesia, bahwa ajaran berwakaf dilakukan oleh pemeluknya. Ketiga, peraturan perundang-undangan tentang wakaf di mulai jaman Kolonial Belanda dan era Reformasi. Keempat, era reformasi secara khusus mengatur praktik wakaf uang di masyarakat baik oleh individu, organisasi, dan badan hukum.

Pekembangan pengelolaan wakaf di Indonesia yang terus berkembang secara lebih elegan dan profesional secara kelembagaan, wakaf tidak hanya berwujud tanah, masjid, sekolah dan benda lainnya ditahan pokok barangnya yang berpola klasik, wakaf berkembang menjadi "wakaf produktif" ataupun "wakaf tunai" yang berdampak besar dalam perubahan sosial dan kesejahteraan, meski secara regulatif pengelolaanya di Indonesia harus berada dalam bagian Undang-Undang Pokok Agraria sebelum adanya Undang-Undang Nomor 41 Tahun 2004 tentang Wakaf. Pasca belakunya undang-undang wakaf ini secara formil negara mengakomudir kebutuhan masyarakat dan implementasi hukum Islam dalam bentuk hukum positif. Hal ini menunjukkan bahwa negara turut andil dan memiliki peran memaksimalkan potensi umat Islam dalam mendorog kesejahteraan masyarakat. Maka, fungsi wakaf dalam hukum wakaf di Indonesia dapat ditinjau dari fungsinya melalui tiga hal (Kencana, 2017: 35) yakni: pertama, berfungsi untuk mengekalkan manfaat benda wakaf sesuai dengan tujuan wakaf yakni melembagakannya untuk selamalamanya guna kepentingan ibadah atau kepentingan umum lainnya sesuai dengan ajaran Islam. Kedua, bertujuan memanfaatkan benda wakaf sesuai dengan fungsinya, dan. Ketiga, berfungsi mewujudkan potensi dan manfaat ekonomis harta benda wakaf untuk kepentingan ibadah dan untuk mewujudkan kesejahteraan umum.

Adanya pelembagaan wakaf yang diatur secara formal melalui perundangundangan tersendiri, senantiasa menyebabkan pengelolaan wakaf menjadi lebih transparan, kredibel, dan akuntabel. Posisi nazhir dan waqif menjadi satu unsur yang saling terkait satu sama lain dalam memaksimalkan potensi wakaf untuk kesejahteraan sosial dan masyarakat (mauquf 'alaih). Oleh sebab itu, pengelolaan harta wakaf dapat dimanfaatkan untuk usaha produktif, misalnya, dapat diinvestasikan pasar keuangan syariah meliputi yang dapat 
sukuk negara/korporasi, reksadana syariah, dan pasar modal syariah. Sementara bila penerima harta wakaf dilakukan oleh LKS-PWU dapat digunakan untuk investasi melalui investasi dalam investasi yang menggunakan akad mudharabah muthlaqoh dan mudharabah muqayyadah. Di sisi lain, untuk investasi pada sektor riil meliputi: perkantoran, apartemen, pusat perbelanjaan, perkebunan, pertambangan, dan lainnya yang memiliki nilai manfaat dan ekonomis yang sesuai dengan syariat Islam. Pasca berlakunya Undang-Undang Nomor 41 Tahun 2004 tentang Wakaf memberikan banyak varian dan pola pengelolaan wakaf secara lebih produktif. Selain itu, peran kelembagaan yang dilakukan organisasi sosial-keagamaan yang telah berpengalaman dalam pengelolaan wakaf semakin kreatif dalam pengumpulan dan pengelolaan wakaf. Hal ini belum lagi peran yang dilakukan oleh LKS-PWU dan BWI yang secara kelembagaan juga semakin kuat dalam pengelolaan wakaf. Maka, untuk meningkat manajemen pengelolaan wakaf dalam bidang usaha produktif dapat melakukan beberapa hal yang dapat memaksimalkan pengelolaan wakaf produktif dengan sistem integrasi

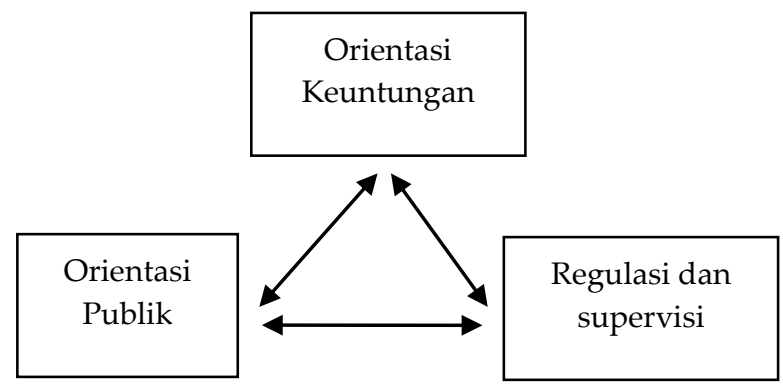

Gambar 1. pengelolaan wakaf produktif

Dalam pengelolaan wakaf produktif, hal yang perlu dilakukan oleh pengelola wakaf dalam memaksimailkan pemanfaat harta wakaf dapat dilakukan dengan tiga hal yakni: pertama, adanya orientasi keuntungan yang dapat dirasakan oleh bagi penerima wakaf (mauquf 'alaih), dalam konteks ini tidak hanya memberikan keuntungan secara materil yang dapat mensejahterakan, melainkan memberikan kesadaran dan edukasi mengenai tujuan dan manfaat pengelolaan wakaf dalam kehidupan umat Islam. Kedua, regulasi dan supervisi berkaitan dengan berbagai perangkat yang dibutuhkan secara formil dalam pengeolaan wakaf, regulasi memberikan pengendalian dan kejelasan secara protektif terhadap seluruh unsur dalam wakaf, sementara supervisi bertujuan agar adanya sistem pengawasan terhadap pengelolaan harta wakaf, hal ini dapat dilakukan dengan dengan adanya penelitian, evaluasi, perbaikan, bimbingan, dan kemitraan (kerjasama). Ketiga, orientasi publik, pengelolaan wakaf produktif mampu memberikan dampak signifikan terhadap kesejahteraan publik dan melahirkan kemaslahatan dengan pilar utama terpenuhinya tujuan syariah (maqashid asy syariah). Dampak kebijakan negara terhadap masyarakat/institusi pengelola wakaf dalam pengelolaan wakaf di Indonesia mampu memberikan ruang variatif dan kreatif dalam pengumpulan hingga pengelolaan harta wakaf. Hal ini ditandai dengan adanya respon negara dalam penyediaan regulasi yakni memberikan penguatan kelembagaan melalui memaksimalkan peran BWI dan LKS-PWU. Implikasinya, pengelolaan wakaf menjadi lebih maksimal dan memberikan dampak signifikan terhadap manajemen pengelolaan lembaga wakaf, tetapi juga pada para penerima wakaf (mauquf 'alaih) yang mampu memberikan kesejahteraan secara umum.

\section{KESIMPULAN}

Kebijakan kebijakan/regulasi negara dalam pengelolaan wakaf di Indonesia 
telah dimulai sejak pemerintahan Kolonial Belanda. Wakaf menjadi institusi keuangan Islam yang ditandai dengan berdirinya Rad Agama atau Pengadilan Agama (priesterrad) berdasarkan staatsblad Nomor 152 Tahun 1882. Pengakuan Belanda berdasarkan penyelesaian hukum Islam seperti wakaf dan lainnya diajukan masyarakat ke Mahkamah Syar'iyyah (Peradilan Agama Lokal), namun dalam penerapannya antara satu daerah dengan daerah lainnya berbeda-beda. Pasca kemerdekaan terdapat beberapa peraturan pemerinah mengenai wakaf. Salah satunya Peraturan pemerintah Nomor 28 Tahun 1977 tentang Perwakafan Tanah Milik yang hanya mengatur mengenai perwakafan tanah saja dan penggunaanya hanya terbatas untuk kegiatan sosial-keagamaan. Namun, pascara berlakunya UU No. 41 Tahun 2004 tentang Wakaf menyebabkan pengelolaan wakaf menjadi lebih variatif dan kreatif termasuk adanya wakaf uang. Dampak kebijakan negara terhadap masyarakat/institusi pengelola wakaf dalam pengelolaan wakaf di Indonesia menyebabkan pengelolaan wakaf harus dilakukan secara kelembagaan dan bersifat produktif. Adanya wakaf uang yang dapat kelelola untuk investasi yang memberikan banyak manfaat kesejahteraan dan kemaslahatan terhadap masyarakat menjadi salah salah satu indikator pengelolaan wakaf secara produktif. Selain itu, penguatan pengelolaan wakaf yang dilakukan oleh organisasi sosial-keagamaan, Badan Wakaf Indonesia (BWI), dan Lembaga Keuangan Syariah Penerima Wakaf Uang (LKSPWU) dilakukan dengan memberikan pemahaman orientasi keuntunngan, regulasi dan supervisi, dan orientasi publlik.

\section{DAFTAR PUSTAKA}

Ali, Muhammad Daud. 1988. Sistem Ekonomi Islam Zakat dan Wakaf. Jakarta: UI Press.

Aziz, Muhammad. "Peran Badan Wakaf Indonesia (BWI) dalam

Mengembangkan Prospek Wakaf Uang di Indonesia." JES (Jurnal Ekonomi Syariah) 1.2 (2017): 188208

Basyir, Ahmad Azhar. 1978. Garis-Garis Sistem Ekonomi Islam. BPFE UGM. Yogyakarta.

Hadi, Solikhul. "Perkembangan Wakaf Dari Tradisi Menuju Regulasi." ZISWAF: Jurnal Zakat dan Wakaf 2.1 (2016): 23-39.

Hastuti, Q. A. W. (2018). Peran Lembaga Keuangan Syariah Penerima Wakaf Uang (LKS-PWU) bagi Optimalisasi Wakaf Uang. ZISWAF: Jurnal Zakat dan Wakaf, $4(1), 41-54$.

Ibrahim, Azharsyah. "Stagnansi Perwakafan di Aceh: Analisis Faktor Penyebab." Media Syari'ah 16.2 (2017): 371-388.

Kuran, Timur. "Institutional Roots of Authoritarian Rule in the Middle East: Civic Legacies of the Islamic Waqf." (2014).

"The provision of public goods under Islamic law: Origins, impact, and limitations of the waqf system." Law and Society Review (2001): 841-898.

"On the notion of economic justice in contemporary Islamic thought." International Journal of Middle East Studies 21.2 (1989): 171-191.

Kendana, Ulya. 2017. "Hukum Wakaf di Indonesia". Malang. Setara Press

Latief, Hilman. 2010. Melayani Umat: Filantropi Islam dan ideologi 
Kesejahteraan Kaum modernis. Jakarta: Gramedia Pustaka Utama.

Mukri, Barmawi. "Implementasi Wakaf Produktif dan Wakaf Tunai Di Indonesia." Jurnal Hukum IUS QUIA IUSTUM 11.25 (2016): 99111.

Moleong, Lexy J. 2001. Metode Penelitian Kualitatif. Bandung: PT. Remaja Rosdakarya.

Rahmawati, Lilik. "Sistem Kebijakan Fiskal Modern dan Islam." OECONOMICUS Journal of Economics 1.1 (2017): 21-48.

Sabiq, Sayyid. 1987. Fiqih Sunnah, cetakan ke-I. Bandung: Al Ma'arif

Sunggono, Bambang. 2007. Metodologi Penelitian Hukum. Jakarta. RajaGrafinfo Persada.

Shirazi, Nasim Shah. "Integrating Zakat and Waqf into the Poverty Reduction Strategy of the IDB Member Countries." Islamic Economic Studies 22.1 (2014): 79108.

Triyanta, Agus, and Mukmin Zakie. "Problematika Pengelolaan Tanah Wakaf: Konsep Klasik dan Keterbatasan Inovasi Pemanfaatannya di Indonesia." Jurnal Hukum IUS QUIA IUSTUM 21.4 (2016): 583-606.

Usman, Husaini, Purnomo Setiady Akbar. 2008. Metodologi Penelitian Sosial. Jakarta: Bumi Aksara.

Qohaf, Mundir. tt. Al Waqof al Islami. Cetakan I. Beirut. Darl al Fikr. 